\title{
Between Fantasy and Realism
}

\section{Gender, Identification and Desire among Korean Viewers of Second-Wave Korean Dramas}

\author{
Jean-Paul Baldacchino | ORCID: 0000-0001-7673-5001 \\ University of Malta, Msida, Malta \\ jean-paul.baldacchino@um.edu.mt
}

\author{
Eun-Jee Park | ORCID: 0000-0001-9098-3108 \\ Pusan National University, Busan, South Korea \\ eunjeepark@gmail.com
}

\begin{abstract}
English-language studies of Korean drama (Korean TV serials) have tended to focus on the transnational consumption of drama in the context of the 'Korean Wave' (Hallyu). Analysing the classification and reception of Korean drama and its interaction with Korean audiences, this paper argues that there has been a significant shift both in the dramas produced and in the audience expectations and interactions with these texts. Building on twenty-one in-depth interviews and ethnographic data, the authors analyse the gendered structures of identification with the characters of dramas. Korean dramas are increasingly held to a standard of realism wherein audiences expect them to represent 'reality' rather than a fantastical escape from it. The authors argue, therefore, that dramas are also fulfilling a social function in being able to represent and generate dialogue over social problems in contemporary Korean society.
\end{abstract}

\section{Keywords}

Hallyu - Korean drama - popular culture - South Korea - gender - realism - Lacan 
English-language, and to a lesser extent Korean-language, scholarship on Korean drama in particular continues to focus on the globalisation of Korean popular culture with little attention being given to domestic appeal and audience interaction in Korea.

Studies of South Korean popular culture have grown dramatically over the last decade. Much of this academic interest is the result of the so-called Korean Wave (Hallyu) phenomenon whereby Korean popular culture (pop music, cinema and television) was transformed from 'an obscure cultural backwater to a new fountain of trendy entertainment in Asia' (Joo 2011, 489), becoming a source of national pride. Prior to its international success, however, Korean popular culture was 'shunned by its own people at home' (Joo 2011, 491; Lee 2012, 449). The term 'Korean Wave' was coined by the media to describe the unprecedented popularity of Korean culture starting in the 1990s (Lee 2012, 448). In the 1990s, K-Dramas were very much at the forefront of this Korean Wave. Foreign success was mirrored by domestic success. By the beginning of the millennium Korean content came to dominate primetime television broadcasts, with Korean dramas far outperforming their foreign competitors in terms of viewer ratings (Joo 2011, 491). Dramas like Autumn in My Heart (2000) (Gaeul Donghwa) and Winter Sonata (2002) (Gyeoul Yeonga) are largely heralded as the first big dramas that launched the Korean Wave phenomenon. Their viewership, however, was largely restricted to middle-aged women (Kuwahara 2014, 215; Mōri 2008, 131). Beyond the dramas themselves there were also indirect economic benefits.

The growth of the Korean Wave has also triggered uneasiness in Korea's neighbours over a new form of 'cultural imperialism', with growing concerns in China, Vietnam, Taiwan and Japan (Joo 2011, 497). It is certainly true that, as Walsh notes, the Korean Wave was very much a 'Korean government construct' with, especially since 2005, the Korean government providing increasing support, including the use of diplomatic resources as well as economic incentives (Walsh 2014, 18). According to Lee, since 2006 the Korean Wave has experienced a decline in the rate of broadcasting exports to Chinese-speaking Asian countries $(2012,450)$. While this decline is partly explicable through 'customers' fatigue with repetitive plots and characters' (Lee 2012, 450), increasing political tensions have also resulted in the decline of Hallyu content among Korea's Asian neighbours. Most recently the Chinese ban on Hallyu (Hanhanryeong) was a retributive decision against the deployment of a defensive missile system (THAAD) in Korea (Park, Lee and Seo 2019). These political tensions have led several scholars to speculate on the death of the Korean Wave.

Despite repeated predictions of the death of Hallyu since roughly 2008, a 'New Korean Wave' or 'Hallyu 2.0' has been identified by media scholars (Jin 
2016; Lee 2012). The second Korean Wave has its own distinct characteristics, with pop music (K-Pop) dominating the scene enabled through social media technologies (Jin 2016, 6). The popularity of dramas has decreased in the Hallyu 2.0 era, with several non-drama genres (the so-called yaenung, including reality shows and audition shows) gradually replacing dramas in many parts of the world (Jin 2016, 50). In spite of the growing popularity of K-Pop over recent years, Korean dramas have grown in appeal in Western countries as well as in new corners of the globe (Lee 2012, 450-452). Popular internet-streaming media-service provider giant Netflix, for example, has invested heavily in its Korean content and streams top Korean titles across the globe (Frater 2019). A similar increase in Korean-content consumption has been witnessed through other streaming sites, such as the now closed Drama Fever and Viki in the US, as well as Viu (Hong Kong) and iFlix (Malaysia).

From a thematic perspective first-wave Korean dramas have often been criticised for propagating an 'idealistic world-view', with 'love' being the 'single most cherished value of Korean Wave serials' (Lee 2012, 454). Many of these dramas created a 'Cinderella fantasy' of young women being rescued by affluent and handsome men (Baldacchino 2008). First-wave Korean dramas tended to be melodramatic in mood and plot, similar to Western soap operas. There is more to Korean dramas, however, than simplistic Cinderella plots. While Korean drama viewership has significantly broadened in Korea itself, with an increasing appeal to audiences in their teens and early twenties, viewer expectations have also been changing. Focusing on the Korean reception of and interaction with Korean drama, this paper argues that Korean TV serials (deurama) can function as 'critical texts' that generate social debate and form a means for South Koreans to engage with the dilemmas engendered by modernity.

A Note on Method and Informants

Conducting ethnographic research in Korea in the 199os, Nancy Abelmann observed that:

There is hardly a page of my fieldnotes without mention of a television soap opera or melodramatic film. It is not an exaggeration to say that the women in these pages considered their lives to be dramatic, not unlike those lives represented in dramas for television and film.

ABELMANN 2003, 22 
When first conducting fieldwork in Korea in 2006 the first author found himself undergoing a very similar experience (Baldacchino 2008, 2014). Almost twenty years have passed since the publication of Abelmann's study and more than ten years since the first author's own work. The primary aim of this study is to explore the relationship that informants have with the Korean drama text. How do young Koreans (mostly women) nowadays identify with such texts? We note, however, that since Abelmann's study the nature of the Korean dramatic text has also undergone a change. This paper is a collaboration between a Maltese anthropologist of South Korea and a Korean film studies scholar specialising in French cinema. It is primarily driven by an anthropological mode of enquiry that seeks to look at dramatic texts in terms of the role that they play in the informants' lives within the context of the broader literature on Korean drama. We cannot say that this study claims to be representative of the Korean population, or any special subset of it for that matter. This study, however, does seek to illustrate the possibility and the range of meanings and interpretations that stem from the text when viewed through the eyes of our participants mediated by our own encounters with Korean society. We develop our understanding of the text through the interpretations that emerged through our encounters with informants. Seen in this light our informants are 'collaborators' in the production of knowledge more than sources of 'data', and we have tried to do justice to their own construction of the world in line with best practices in critical anthropology that seeks to understand a phenomenon from the 'ground up'. We have chosen to sacrifice quantitative representativeness in favour of an intimate understanding of the drama as a lived text.

To this end the first author conducted a series of twenty-one in-depth interviews over 2018-2019 supplemented by hundreds of hours throughout the years spent discussing Korean dramas with Koreans from all walks of life. The production of this article involved many hours of discussion between the authors which constituted another layer of cross-cultural collaborative knowledge production in its own right, mediated by our own different disciplinary backgrounds. The participants to this study were recruited by means of public announcements on campus in a private university in Busan. Though not all the participants were from a particular school, by and large the people interviewed came from a middle-class background. Some of the informants in turn introduced the interviewer to their friends who also wanted to participate in the study. No manner of inducements were offered to the participants. Interviews were conducted in cafes and restaurants, and on occasion on campus itself. Interviews varied in length, ranging from one and a half to three hours. In some cases the first author also met with informants on 
more than one occasion as a rapport developed with the informants. Questions in the interviews were mostly directed at informants' viewing patterns and their perceptions of Korean dramas, though these dramas were often brought into discussion with the informants' views and perceptions of the world as really constituted. As noted further on, the relationship between drama and reality was a topic which frequently appeared in the course of our research and it was something that our informants themselves were acutely conscious of. The ages of informants ranged from 20 to 27 years old. While the call for participants did not specify gender, most of our informants were women (eighteen). Much of the commentary below is therefore derived from a female gendered perspective. The three interviews with men, however, were also particularly insightful in their own right in so far as they highlighted possible differences in the relation to dramas on the basis of gendered identities and ideals, as will be discussed further on. In this paper we will discuss audience reactions to a number of dramas. The discussion of the dramas is selective. While there were other second-wave dramas that were particularly popular and significant over the last decade, this paper focuses its discussion on a selection of dramas which were popular at the time that the research was conducted and reflects the importance given to the dramas by our informants.

\section{Notes towards a Typology of Korean Drama}

Under the umbrella term 'Korean drama' there have been various types of drama since the early 200os. During the course of the interviews, whenever informants mentioned drama titles the researcher would ask them to describe the drama in their own words. In one particularly useful interview Su Mi, a 24-year-old female computer studies student, advised the interviewer that he needed to understand the different types of drama. The following is an excerpt from the first author's fieldnotes:

Su Mi was quite energetic and evidently relished talking about dramas. Grabbing the pen from my hand she asked to use the notebook and she drew an organogram with different kinds of drama. It seemed clear that while she had a general idea of what to include she was very much working this out in the course of explaining it as she paused to think to flesh out her model. When asked about specific dramas she proceeded to place them in her categories. 
While this study did not originally set out to build a typology of Korean drama, following informants readily agreed with Su Mi's basic typology, while some disputed certain evaluative and descriptive references to particular types of dramas, which will be discussed further on.

One may indeed question the 'objective' validity of a typology ultimately derived from such a subjective source. Any typology is ultimately a system of classification and, much like myths and kinship systems, is ultimately a 'cultural artifact'. While the analysis of systems of classification has been a characteristic feature of anthropological thought, this has usually been applied to religious systems and kinship structures; however, we argue that such an approach is equally important when studying the contemporary mundane world of KDramas. Such a system can provide a useful way of understanding the meaningful categories by which the world is constructed even though it is ultimately a classification of its imaginary formations.

The following section will discuss this typology of Korean dramas as developed by our informants. Following Yang, we consider genre as 'the result of a social and historical process rather than a set of textual elements' (2008a, 79). In this typology it is important to note that while the analysis is the authors', the terms and the categories emerged from our informants' own classificatory systems. The typology seems to be based on three criteria - time of airing, targeted audience and content. When discussing deurama informants generally referred to television mini-series, typically between sixteen and twenty-four episodes, with each episode lasting less than an hour.

Our informants distinguished clearly between three different categories of deurama. Achim deurama (morning dramas) are generally targeted at an older female audience. They run for much longer than standard mini-series and resemble the Western soap opera. During lunchtime, small restaurants often have the TV tuned to such dramas with the restaurant's ajumma (aunties) peeling vegetables and watching the drama on quieter days. Weekend dramas ( jumal deurama) are generally considered family entertainment. These include sageuk deurama (period dramas) which, according to our informants, were generally preferred by their fathers. These dramas are generally set in Korea's pre-modern past, either in the Koryo (918 CE-1392 CE) or the Goguryeo periods (first century вСЕ-seventh century CE). Recent research in the Korean film industry has drawn attention to the revival of the historical drama. From the late 199os, because of 'shifting audience tastes, coupled with changing public memory of the national past ... television started airing extremely popular sageuk dramas' (Hwang 2011, 97). These sageuk dramas have provided important vantage points from which to explore the self-construction and representation of national identity, becoming 'a window into the way contemporary 
Koreans perceive their past' (Hwang 2011, 83). Among our informants there was some debate as to what constituted a sageuk drama.

Descendants of the Sun was a hugely popular Korean drama that aired in 2016 and was set in the context of a peacekeeping mission in the fictional country of Uruk, located in the contemporary Balkans. It is interesting to note that, during discussion of sageuk drama with some informants, debate arose as to whether or not Descendants of the Sun was indeed a sageuk drama. At one point during fieldwork the first author was engaged in a discussion with two undergraduate female students attending a prestigious national university. When asked for examples of recent successful sageuk dramas they had enjoyed, Myeong Jin, a 24-year-old literature student, mentioned Descendants of the Sun. Her friend, Su Mi, looked quizzically at her. Turning her head to one side, she pointed out that to her recollection the drama was entirely fictional, which led to a discussion as to whether Descendants of the Sun was historically based or not. Flamm (2018) provides an insightful analysis of Descendants of the Sun wherein he points out that the historical omissions or reference to the UN context in this drama are devices intended to 'normalize troop deployments in everyday domestic discourse' $(2018,6)$. While actual historical referents are indeed absent in this drama, it is constituted in such a manner that a historical context is assumed, and indeed part of the success of the drama depends on the implicit connection to the Korean geo-political context, even though one cannot ignore the fact that the 'the drama attempts to project a favourable image about Korea to the outside world, in line with recent nation-branding campaigns by Seoul' (Flamm 2018, 6).

The revival of the sageuk genre led to a neologism that highlights its hybrid qualities: 'fusion sageuk'. There is indeed an increasingly important trend in combining fantastical elements (pantaji) with historical referents. However, with the exception of one female informant who is a student of history, most of our informants did not seem to have much interest in the sageuk dramas per se and largely associated the genre with a male viewership, in spite of the fact that the new sageuk is explicitly pursuing the attention of female audiences especially the younger demographics' (Hwang 2011, 84).

Over recent years pantaji (fantasy) dramas have become increasingly popular. Guardian: The Lonely and Great God (Sseulsseulhago challanhasinDokkaebi), produced by tvN, for example, became a national sensation in 20162017. The drama follows the life of an immortal goblin (dokkaebi) and his grim reaper friend ( jeoseung saja). The male protagonist, Kim Shin (acted by Gong Yoo), a general in Goryeo times, is cursed with an invisible sword in his back which prevents him from dying. Only a pure woman, destined to be his wife, can liberate him from his curse. The female protagonist in the drama is a poor 
and orphaned high school student, Ji Eun Tak (Kim Go Eun). As such, the drama could be considered part historical in nature and could possibly be classified as a 'fusion sageuk', given the interplay of fantastical and historical themes. Even though it aired on a cable channel/pay TV, the drama broke records, with the final episode registering 18.68 per cent of the average audience share, according to the Nielsen polls. Many informants liked the drama because it was fresh and exciting (singihada).

Family dramas (gajok deurama), on the other hand, where the main theme of the drama revolves around family and everyday life, are normally preferred by mothers. That being said, recent studies seem to indicate that the gendered viewership might not be as clear-cut as it seems, with the rise of ajeossi (uncles) joining soap opera fandom (Kang, Im and Noh 2012, 202), although generational differences seem to be more hard and fast. While some of those interviewed watch these dramas together with their families at the weekend, most of our informants followed weekday dramas (pyeongil deurama), which occupy the prime-time evening slots from Wednesdays to Fridays. For many informants the weekend dramas are far too ridiculous and have unbelievable plot twists. They described these somewhat pejoratively as makjang deurama, meaning 'unrealistic' and 'overly melodramatic', with typically formulaic plot devices. First-generation Korean dramas such as Winter Sonata and Autumn in My Heart, referred to earlier, are indeed deemed to be unwatchable by the younger generation, who consider them makjang deurama. Weekend dramas were similarly criticised, though many female informants watched these dramas with their parents as a family activity.

Whereas in the past it was generally the free-to-air national broadcasters such as КвS, SвS and MвC that cornered the market, over recent years cable television companies have started producing their own dramas. Even though, according to Jin, cable channels 'cannot compete with networks in the realm of dramas due to their lack of budget and expertise' (2016, 51), many second-wave cable Korean dramas have outperformed their network rivals. Cable TV networks have steadily increased ratings and have introduced several innovative approaches to the genre from the mid-2010s. This has in turn prompted the freeto-air TV networks to go beyond the comfort zone of melodrama and romantic comedy as a result (KOССA 2014, 66-67). Many of the people interviewed believed that cable companies are more likely to be bold and experimental, while free-to-air network companies are subject to more rigid censorship of profanity and physical intimacy. It is unclear how much of this censorship is actually imposed by law as opposed to a certain conservative self-censorship. Perhaps the growth of cable television channels as producers of dramas is one of the most significant differences between first- and second-wave Korean dramas. 
This rise in the popularity of private cable companies is not only indicative of expansive investment by media groups like CJ E\&M but also a sign of the increasing proliferation of modes of viewership in the second wave. While DVD sales of Korean dramas are uncommon, in Korea there is an increase in streaming services which have made Korean drama content widely available. Our informants watched dramas on their laptops and smartphones as well as on TVs. Many of our informants wait until the show ends and download or stream it in its entirety. The increased flexibility of modes of viewership, however, has meant that watching dramas might have become less of a social event and more of a private one. Yu Na, for example, is a female university student in her early twenties. She aspires to become an air hostess. She lives in a dormitory, since her mother works in another city and her father is working overseas. She does not watch a drama week by week but instead downloads an entire season and watches it on her laptop.

Part of the recent change in Korean drama involves a greater diversification within the genre. Whereas in the past most dramas could be classified as melodramatic soap operas, over the last seven to eight years a greater variety of dramas have been aired 'beyond the traditional generic palette coloured by melodrama and romantic comedy' (Kim 2019, 5). New generic developments include horror, legal thrillers, crime dramas and, most recently, fantasy. Korean films and dramas have shown a remarkable capacity to appropriate and modify Hollywood genres, displaying a high degree of generic hybridity (Kim 2019, 4; Jin 2016, 68-90). Since the second Korean Wave, genre format exporting has been one of primary concern in Hallyu, with the products going through experiential modes of amalgamation to adapt to the global scale (Kim 2018, 23).

Two of the features singled out by interviewees as most important when watching dramas are the OsT (original soundtrack) and the actors themselves. The soundscapes of Korean dramas are so intimately associated with the experience of watching a drama that when a drama is exported it is not uncommon for record companies to buy airtime in the opening and end credits (Kim 2005, 201). The importance of the ost cannot be overestimated in Korea either, as the songs, in particular, function as a cultural code invoking 'our nostalgia for a lost community' (Yun and Kang 2014, 54-55). In Korea the soundtrack of popular Korean dramas has become a ubiquitous part of the Korean soundscape and provides an important means to relive the drama and its characters. Eun Hee, for example, kept listening to the soundtrack of Oh My Ghost (2015) (O Naui Gwisinnim) long after the drama ended. She found that the soundtrack helped her relive the feelings of the protagonist in the drama-in this case a young ghost who is seeking to find peace. In particular she found that the song 
'Leave', sung by the actual actor in the drama (Park Boyoung), evoked a certain feeling of transience when looking back over one's life, which moved her deeply (doedora boda).

Actors starring in Korean dramas often become international stars with a fan base across the region. Much has been written on the popularity of Korean male stars in constituting the Korean Wave (Lee 2010, 71; Yang 2008b, 287) This 'star factor', however, was also important among our Korean informants. Some of our informants would choose to watch a drama because it starred particular actors. Hye In, for example, is a 2o-year-old student who lives and studies in Busan. Her parents run a small family restaurant in the city. She aspires to find a job overseas in a company or else as an interpreter. She loved Guardian because 'the actors are so beautiful'. Joong Ki, one of the few male informants interviewed, told us that his favourite drama was also Guardian because, apart from being action-packed and having fantastical themes, it starred Gong Yoo and he 'trusts him'. For Joong Ki it is the actor's performance and skill which is the most important element. Ah Reum is in her last year at university and is the daughter of a bus driver and a kindergarten teacher. Her favourite drama is the 2014 romantic comedy Discovery of Love, mainly because of the actress Jung Yu Mi. She has re-watched the drama more than once because of the female protagonist. For some, however, the star factor is a symptom of the superficiality of the audiences of Korean dramas. According to Tran, 'regardless of talent, physical appearance takes more of the phenomenon into account' $(2015,57)$. The idealised representation of the beautiful Korean stars, according to Tran, leads to increasing numbers of young people undergoing plastic surgery in order to resemble the idealised images of beauty represented by these stars (Tran 2015, 60 ). In her chapter on the star as a genre in Korean popular cinema, however, Cho argues that the star 'functions as a container for individualized manifestations of group feeling, in a shifting field of differential relations between concepts of national, ethnic and popular identity' $(2014,190)$. The racial politics of Hallyu stars provide a personifiable form of self-ideal (Hong-Mercier 2013, 173174), offering, at least for a domestic audience, an outlet for cultivating a 'culture of the self' that can bypass the established notion of Westernised beauty and instead gives a feeling of subjectivity and closeness, making the domestic audience feel that 'you can sit next to them' (Lee 2008, 74). In this respect we believe that while it is true that the physical beauty of the actors is a factor attracting audiences, and has certainly been used as a strategy to market dramas overseas, viewers are also drawn to the characters over and above the actors themselves. As we discuss in our following sections, our research confirms that audiences do indeed form a personal engagement with the characters in the drama rather than simply with the stars who play them. 
Identification in first-wave Korean Drama scholarship has been read as a form of alienation making people 'forget, no matter how briefly, their frustrations with reality' (Lee 2012, 458). In terms of their sexuality female characters are often depicted as passive and sexually pure (Prado 2017, 147). ${ }^{1}$

Commenting on recent dramas, Tran argues that the popularity of South Korean dramas shows a fantastical alienation where their fantasy results in the desire to be or act like the Hallyu star image (Tran 2015, 58-6o). Trying to become like the Hallyu stars often results in attempts to transform the body through plastic surgery. Indeed, Eun advocates capitalising on the regional popularity of Hallyu to turn Korea into a hub for aesthetic surgery (Eun 2013, 1561). Others have argued that dramas reproduce traditional gender stereotypes 'reinforcing Korea's "unfailing" patriarchal culture' (Lin and Rudolf 2017, 49).

What is often missed in these discussions is the sense of intimacy that develops in the relationship to the character in the drama. Ha Na is a 26-year-old graduate student from Busan, living with her parents, who are retired teachers. She actively rejects any traditional gender roles. She does not want to get married since she feels it will make it more difficult to succeed at work. Ha Na feels that marriage would not be enough for her. As such she is drawn to female leads in dramas that reflect her own idealised personality. She was particularly drawn to the character of Hong Seol (Kim Go Eun) in Cheese in the Trap (Chijeuindeoteuraep), which aired on the cable network tvN in 2016. According to $\mathrm{Ha} \mathrm{Na}$, the drama portrays a realistic view of the relationship between people in college. Hong Seol is not from a rich family and lives in an apartment. She struggles to keep up with her life-juggling the demands of family, friends, boyfriend and study. Ha Na particularly liked the fact that even though the boyfriend in the drama is like a 'prince' Hong Seol does not rely on him and is not seeking to be rescued but manages her own life. Ha Na wishes she could be as strong and independent as Hong Seol and she feels bad because she feels she is lazy compared to her. For Ha Na it was precisely Hong Seol's independence that attracted her to the character. $\mathrm{Ha} \mathrm{Na}$, however, is anything but a lazy character. At the time of the interview she was studying and working and indeed had to cope with the demands of friends, family and her own relationship, although she herself struggled with her own educational aspirations since

1 Interestingly, however, the 2015 drama 'Oh My Ghost' (O Naui Gwisinnim) had, as a female protagonist, Kim Seul Gi cast in the role of a voracious succubus-like ghost (Shin Sun Ae) who died a virgin and needed to release this unresolved grudge (han) by having sex; however, her kiss was deadly and drained the life out of her unfortunate suitors. 
she had not yet managed to get into the graduate programme of her choice. In this regard, Ha Na seems to actively resist any traditional gendered script. She was herself well aware that the female characters in many dramas, especially of the first wave, represent a 'fantastical' Cinderella-type script. She did, however, look towards strong and independent female characters as sources of inspiration. This was a commonly shared sentiment. Mi Na, for example, felt a particularly close connection with the character Hye $\mathrm{Na}$ (Kim Bo Ra) in the 2018 hit drama SKY Castle because she 'always finds a way to do what she wants and she is clever'. When asked if she wanted to be like her, she said: 'Her family is not a good family but I would like to be like her.' Mi Na confessed that even though she watches dramas on a weekly basis she finds that many Korean Dramas are far too romantic. She prefers realistic dramas with more 'tragic' endings.

Eun Jin is a 25-year-old student living with her family in the affluent area of Haeundae in Busan. She wants to work in a media company and watches a lot of dramas on a weekly basis. One of her favourites is Reply 1994 (Eungdaphara 1994), which is centred around the lives of six young university students from provincial areas studying and living together in Seoul. The drama aired in 2013 on the cable channel tvN. It is set in 1994 alternated with scenes from the present. Eun Jin aspires to be like Sung Na Jung (Go Ara) who is an easygoing computer science student. She describes her as 'active, fun, kind and a good person loved by many people'. She thinks of her as a template to emulate. That said, Eun Jin likes watching love stories with happy endings in dramas even though she clearly thinks that the 'Cinderella love stories' in dramas are unrealistic. She distinguishes between an 'unreal love'- that between a rich girl and a poor person - and a 'real love' such as that in the family. There seems to be a continued sense of ambivalence towards an idealised notion of romantic love in Korean modernity (Baldacchino 2008).

As can be seen from the preceding discussion it is difficult to categorise attitudes according to class. While most of the people interviewed were middleclass women and were indeed drawn to strong independent female characters, they were not blinded by a consumeristic ideal. In fact, many of our informants were themselves highly critical of product placements in Korean dramas. This is not to say that all informants did not appreciate the more aesthetic qualities of the characters. Chan Ri was one of our older informants. She is a 30-year-old art history graduate student. She watches drama for an average of five hours per week. She doesn't like fantastical dramas and prefers more realistic ones. She found Guardian, for example, to be too childish and unrealistic. One of her favourite dramas is Coffee Prince (2007) (Keopipeurinseu 1 Hojeom) because she believes that it portrays a realistic connection between couples. She cried many 
times watching the drama and saw herself in the character of Han Yoo Ju (Chae Jong An). The character is an artist who is both 'stylish' and 'professional'.

Lee argues that within the text of the drama the female protagonists are positioned as the Lacanian objet a (object a) in so far as they represent the imaginary, unobtainable object, being both object and the cause of desire $(2012,457)$. The representation of female characters as being 'pure' and 'perfectly good' portrays an idealised femininity personified in these female protagonists. For most of the people interviewed in our study the protagonists did indeed serve as imaginary representations of ideal selves. The idealised representations of femininity within Korean dramas are perhaps more aptly described as representations of the imaginary phallus. ${ }^{2}$ Lacan designates two positions in relation to the phallus, a 'feminine position' wherein one seeks to become the object of desire and the 'masculine position' where one seeks to have the object of desire. In second-wave dramas the woman is often placed in the position of the phallic object thanks to her beauty, kindness and purity. This is certainly the case, for example, in one of the dramas that was popular while fieldwork was being conducted in 2018, My ID is Gangnam Beauty (Nae aidineun gangnammi-in), which aired on a cable channel (Јтвс). In the drama the female protagonist is a humble university student, Kang Mi-Rae (Im Soo-Hyang), who becomes the phallic object par excellence. She is chased by every man in the university. In the drama she is actively pursued by the handsome, strong, 'cool' and wealthy Do Kyun Seok (Ch Eun Woo), among others. The male characters in the drama look on the woman as the beautiful object and the entire plot of the drama revolves around the male protagonist chasing the phallus embodied by the unique and perfect woman in the drama.

It must also be noted that second-wave Korean dramas are increasingly turning towards a more unorthodox representation of femininity. The 2017 MBC drama Weightlifting Fairy Kim Bok Joo (Yeokdo-yojeong Gim Bok-ju), for example, features a female weightlifter athlete who enjoys eating and repeatedly physically intimidates men, including her eventual boyfriend. The female character is both strong-willed and physically strong, defying the conventional soft gendered representations of femininity. That said, while Weightlifting Fairy Kim

2 The objet a in Lacanian thought, however, is a concept that has evolved with his writing. In his later Seminars the notion of objet $a$ takes a very particular meaning - the $a$ in object $a$ comes to designate the Real object (as opposed to the imaginary object): what in his Seminar VII Lacan referred to as 'the Thing' (Fink 2016, 194) and we are therefore by definition outside the limits of the Imaginary. The phallus in Lacan is distinct from the physical organ-the penis-and functions as a signifier denoting value. 
BokJoo garnered a cult following it failed to become a commercial success; only a few of our informants actually watched it, and those that did, did not finish it.

It is difficult to classify second-wave dramas as being simply ideological reproductions of traditional gender norms. Most of our female informants actively refused to identify with the position of the woman as imaginary phallus as represented in many of these dramas; rather, they chose modes of viewing the character from a different subjective position.

In spite of the literature which shows that Hallyu was originally driven by the male star's power to capture the fantasies of a female audience (Lee 2010), our interviewees rarely mentioned the male protagonists in the dramas. Their focus was almost exclusively on the female characters. These characters functioned as an ideal-ego for many of our female informants.

Building on Freud, Jacques Lacan discusses the concept of the ideal-ego (moi-ideel/Idealich), in terms of the narcissistic capture of the imaginary. This ego, however, is always an idealised vision of oneself. The ideal-ego exists in an ambivalent relationship to the subject. It is both loved and hated since this is also the 'unattainable place of perfection' (Chiesa 2007, 20). It should hardly be surprising that the ideal-ego is often provided to us from somewhere outside the individual in the age of mirrors and selfies (Fink 2016, 73). The ideal-ego projected on to female protagonists in Korean drama provided many female informants with idealised versions of themselves-images which at the same time they feel they fall short of achieving — and often eliciting ambivalent feelings. Interestingly enough, however, these images are not validated by a male desire.

One can appreciate the significance when one contrasts this with the way male informants approached Korean dramas. Male characters in dramas could also provide points of identification for male viewers. Joong Ki is a 24-year-old male student from a middle-class family. Both of his parents are in their fifties and work in a government agency. He was very critical of the ways in which males are portrayed in Korean drama, believing that such men set impossible standards:

The male characters are always strong, clever and rich. I look at dramas and I want to be like those male characters. So I follow them. When the characters meet their girlfriends they are always so gentlemanly, you know, like always offering her his seat and so on.

Joong Ki looks at these male characters as idealised versions of masculinity even though he resents the impossible standards they hold men up to (ambivalence of the ideal-ego). There is, however, an added step to this imaginary rela- 
tionship, which at this point is fundamentally triadic. In Joong Ki's words: 'I look at drama and I study it, I guess, unconsciously, because girls want guys to be like that. The guys are always gentle and kind.'

In a way, Joong Ki's response hints at the feelings of uneasiness expressed by the male audience in East Asian countries from the experience of seeing these idealised male characters, resulting in negative views on Korean dramas (Shim 2003, 417). That said, contemporary Korean dramas also contain the potential to recreate new points for cathartic identifications with counterhegemonic masculinities. Elfving-Hwang (2017) discusses at length the drama Incomplete Life (Misaeng) (tvN, 2014), which represents the precariousness and frustration of 'underdog salaryman masculinity' (2017, 56). Following the 1997 financial crisis, the dominant hegemonic masculinity of the corporate warrior began to show cracks. Elfving-Hwang argues that 'Misaeng represents a counter-discourse that aims to reclaim hegemonic masculinities from neoliberal materialism' $(2017,66)$. Joong Ki and the other male informants in our study, however, did not watch or make reference to Misaeng. Joong Ki ultimately looked to drama to learn a thing or two about woman's desire. Lacan famously formulated that desire is always 'other': 'Which basically means that we are always asking the Other what he desires' (Lacan 2008, 38). In this case Joong Ki answers the question posed by desire by looking towards the male protagonists in dramas. His ideal-ego is the result of an interpretation of the other's desire, by what he generalises as woman's desire.

Interestingly enough, Joong Ki seems to reverse the reading of dramas taken by many scholars. Dramas for Joong Ki do not reflect an androcentric constitution of the female object of desire but rather they represent the idealised object of female desire. What both Joong Ki's and the conventional scholarly readings of Korean dramas miss, however, is that behind the veil of the imaginary relationship of love there is a very different identification in play for the female subject. Our female viewers did not identify with female protagonists in order to project their fantasy for an idealised male 'prince'. Female informants projected an ideal-ego into the personalities of the dramas looking for strong, fierce, independent, kind, fun and successful role models. Identification was often expressed as empathy (gonggam) with the characters in the dramas. Informants could relate experiences of the characters to those in their own lives (such as parental pressure for educational achievement, ambivalence towards the prevailing cult of plastic surgery, etc.). Through watching such dramas our female informants also felt that they could express themselves and their emotions in ways which they would otherwise find difficult. Da Eun is a 23-year-old female student. She believes that many young Koreans can relate to characters in dramas because these characters are able to express a personality which 
for many of them is difficult. She believes that 'all Asians, even Japanese, don't express their thoughts openly'. However, the characters in Korean dramas are full of confidence (jasingam). While 'Korean culture is not direct in Korean drama characters express their thoughts naturally, confidently and powerfully.' Many informants enjoyed watching dramas because it allowed them to express their own feelings through their sympathetic identifications with the characters. Da Eun, however, seemed torn about this ideal-ego. She said that she does not aspire to be like that, since 'expressing oneself freely is not good to others'. In this sense the ideal-egos represented through female protagonists in Korean dramas were not read as products of male patriarchal desire but, rather, they expressed a desire developed in opposition to the prevailing allocentric moral order.

In part this reading is enabled by a certain transformation in the texts of second-wave dramas that, to some extent, are challenging hegemonic visions of society. Many of our young Korean informants expect dramas to correspond to their own definition of reality. The subject of the realism (hyeonsiljok) of Korean dramas was frequently brought up by our informants. Dramas were often criticised for being unrealistic (bihyeonsiljeogin). This standard of 'reality' applies not only to the gendered portrayals of subjectivity but also to the portrayals of the modern social order, echoing in some respects the scholarly critique of the melodramatic representations in Korean dramas. ${ }^{3}$

Both the melodramatic genre in general (Storey 2015) and Korean dramas in particular (Park 2013, 348; Hong 2014, 17) were often criticized for portraying an idealised world. Many of the viewers interviewed, however, were adamant that current dramas differed significantly from those of the original Hallyu. One of Eun Jin's favourite dramas was the aforementioned sKY Castle (SKY kaeseul) which aired in 2018-2019 on a cable channel (JTBC). SKY is also an acronym which is used to refer to Korea's most prestigious universities (Seoul National University, Korea National University and Yonsei University). The drama focuses on a group of wealthy housewives living in a luxurious area of Seoul and the extraordinary lengths they go to in order to ensure that their children gain admission to the prestigious Seoul National University. For Eun Jin

3 Park (2014) argues that the trendy, fairytale-like romanticism of Korean dramas draws heavily on 'improbable plots' and 'overly melodramatic sensibility', whereas for Hong (2013) this questionable representation of East Asian modernity is amplified through Korean drama. 
SKY Castle portrays real Korean society as it currently exists. Dramas such as SKY Castle, according to Eun Jin, 'show facts and the not so good parts of society ... it is realistic', a sentiment widely echoed by other informants when discussing this drama. For many students the university admission examinations were a hellish experience (siheom jiok, literally 'examination hell'). Students face extraordinary pressure and the family invests heavily in students as they prepare for their university entrance exams (Lett 1998; Seth 2002). This 'education fever' is also tied, in part, to class aspirations (Lett 1998, 159). While $S K Y$ Castle depicts an upper-class world far removed from that of our informants' middle- to low-income families, all of our informants were captivated by the drama because it 'shows the reality of student and family life', as Min Ji put it, including teen suicides. Even though this was not 'their' reality —in so far as our informants did not come from such wealthy backgrounds-informants were convinced that this drama shows a 'real Korea'.

Many of our informants found personal points of connection with this drama. Hee Jin is a 22-year-old student. Her preferred dramas are 'realistic' dramas. She liked $S K Y$ Castle for this reason and she has watched the whole drama more than once. She felt that it really showed how competitive the school system is and she could sympathise with the children in the drama and their conflicts with their parents. It is certainly true that parental expectations in education, career and marriage often create a conflicted emotional relationship with enduring feelings of guilt when children feel they are not able to live up to their parents' expectations (Baldacchino 2014). SKY Castle dealt with desire and subjectivity in the realm of education and family (G. Han 2019, 307), unwittingly becoming a forum for Koreans to discuss the difficult issue of 'powerful parents' and their 'ever-infantilized children' (Cheon 2019, 426). For some of our informants who had only recently entered university this was indeed a sensitive subject. For Ji Hee SKY Castle was also one of her favourites. It wasn't really a romantic drama, according to her, but focused on the 'real issues' and the tensions that children have with parents. It was evident that she felt a personal connection with the drama. In this case the focus was not on the identification with an individual protagonist but rather on the ways in which a social reality was given a representation that resonated with the informants' own experiences. When asked whether she had to undergo similar tensions with her own family she was reluctant to talk further on the subject. Talking about dramas was often the only way to discuss the family problems that informants were facing, since they were uncomfortable depicting anything but a harmonious domestic environment.

The second drama which was airing during fieldwork and garnered a lot of attention from our informants was also a cable drama which was originally a 
webtoon. ${ }^{4}$ Gangnam Beauty (2018) centred around a female protagonist, Kang Mi Rae (Im Soo-Hyang), who suffered a lot in school because of her ugliness. In school she was teased as 'Kang Orc'. Before going to university, however, with the support of her mother and unbeknown to her father, Mi Rae had plastic surgery. Mi Rae's father opposed the surgery, probably reflecting a more traditional 'Neo-Confucian' outlook where body modification is morally suspect (Kim 2003, 98). The drama centres on the importance of looks and the prevalence of plastic surgery in South Korean society. As Kim notes, 'beauty has become the new standard of a woman's value' (Kim 2003, 103). Beauty has been widely recognised to be a determining factor in one's occupational possibilities. On one hand, the character of Mi Rae is seen as both a reflection of this value and a victim of it. In the drama Mi Rae looks at every person and is immediately able to tell what surgery they have had, giving them a score on the basis of their looks. On the other hand, she herself is very self-conscious about her own artificially acquired good looks and in the first few episodes she is in constant fear that people will find out what she really looked like. The drama repeatedly creates and plays on the contrasts between a natural beauty and an artificial beauty.

The term Gangnam miin (literally 'Gangnam beauty') is a derogatory one, used to refer to women who have undergone plastic surgery. It implies that they are both superficial and artificial, and that they are all alike. 'Gangnam' refers to the eponymous district in Seoul. The district itself is an important signifier in Korean culture. Living in Gangnam, south of the Han river, is a sign of material and social success (Lett 1998, 105). In episode 11, in what is intended as a piece of comic relief (but is ultimately a form of classist humour), Mi Rae's taxi-driver father and her mother overhear passers-by commenting on Mi Rae's looks as a Gangnam Miin. The parents, however, are not aware of the meaning of the term and feel flattered, noting that she is 'not just a miin [beautiful woman] but a Gangnam miin!' In the following episode her father, while driving a young man in his taxi, shows him a picture of his daughter and proudly tells him she is a Gangnam miin, as the young man struggles to hold back a smile. Similarly her mother asks her hairdresser for a 'Gangnam-style' haircut. Gangnam first drew the attention of international audiences through Psy's YouTube sensation 'Gangnam Style'. Incidentally, while the song was catchy and the video ridiculous, many international viewers did not realise that the song was also a piece

4 This seems to be an increasingly important source of inspiration for the Korean film and TV industry. Several recent movies and dramas originated as immensely popular webtoons. These include Misaeng (2014), Cheese in the Trap (2016), My ID is Gangnam Beauty (2018) and the big screen sensation Along with the Gods (2017). 
of social satire poking fun at the excesses of consumption in modern Korea (Jin $2016,126)$. The point is not incidental in that Korean popular culture has begun to adopt an increasingly critical turn in the last decade.

Tran argues that in modern South Korea 'plastic surgery is the main tool to boost one's self-confidence in terms of selling their resume, marriage, achieving normalisation, and therefore, happiness' $(2015,61)$. The practice of double eyelid surgery as a high school graduation present has become so common that it has become almost a rite of passage (Kim 2003, 105). It would be outside the scope of this paper to trace the cause for the incidence of such high rates of plastic surgery; however, Gangnam Miin could be read as a critique of superficial evaluations of people based on standards of beauty while at the same time highlighting the paradox that many young women have to live through.

Hee Jin, a 22-year-old female communications student at a small private university, felt she could sympathise (konggam) with the protagonist. Mi Rae feels that she has to respond to the social pressure placed on female appearance by undergoing plastic surgery, but throughout the show she is facing ridicule and criticism for not being a natural beauty. Hee Jin personally felt this societal pressure and would consider having plastic surgery herself. $\mathrm{Yu} \mathrm{Na}$, on the other hand, didn't like the drama. She believed that it is ultimately too much of a 'Cinderella story'. She judged Mi Rae quite harshly since in the drama Mi Rae herself evaluates people according to their looks. Mi Rae in her opinion was a weak female character - the man is always saving her and carrying her. The male protagonist is Do Kyung Seok (acted by the singer/actor/model Cha Eun Woo) who, according to $\mathrm{Yu} \mathrm{Na}$, is 'handsome, perfect, strong', unlike the weak female lead. In the story we learn that Do Kyung Seok knew Mi Rae in high school before she had plastic surgery and had already developed feelings for her back then. In fact, Do Kyung Seok takes on the role of a moral agency. He does not value people for their looks and even criticises Mi Rae for her superficiality. In turn Mi Rae herself acts as a moral agent, pushing Do Kyung Seok to reconnect with his estranged mother, who we learn was a victim of domestic abuse. The drama reinforces a certain moral universe that emphasises the importance of forgiveness and establishing good family relationships, and could be said to enforce a message that drew Yang's (2008) Taiwanese working-class informants, with a focus on familial relationships. On the other hand the drama could be read, as it was by most of the informants, as a critique over a superficially obsessed society where 'knife-style is life-style' (Tran 2015, 63), which places women in an impossible position.

Twenty-eight-year-old Tae Sun spoke at length about the drama. He described the drama as a 'feminist drama', viewing it as a portrayal of women's suffering in contemporary Korea with the social pressure to be beautiful because 
of men. After a while in our discussions, however, Tae Sun declared that he did not actually like the drama: 'I'm a man. I can't really connect with the story.' The case of Tae Sun is particularly interesting because it shows the ways in which dramas go beyond vicarious fantasies but can themselves become social and indeed dialogic texts-albeit gendered ones. Tae Sun confessed that he only watched the drama because his girlfriend 'made him watch it' so that he could be made to understand the plight of women in Korea. While this is probably quite an exceptional case, it does show the ways in which dramas can indeed act as a critical mirror for Korean society. For our informants it is these kinds of dramas that are 'realistic' dramas, and the fact that such cable dramas topped national viewer charts is a testament to the changing nature of second-wave audiences no longer merely content with Cinderella stories.

\section{$5 \quad$ Conclusion}

Korean dramas have become increasingly complex polysemic texts that allow for differing interpretations of social reality. Indeed, there is a growing concern among policy-makers and academics that such dramas might shape the attitudes of young Koreans in a way that does not reproduce the agenda of the nation-state in developing productivity. In a 2010 study Jin and Jeong examined the effect of South Korean drama consumption on the perceived prevalence of single life and having fewer children in married life. The authors found that 15 per cent of all dramas aired between 2005 and 2007 portrayed single living and career women's childless life in a positive light (Jin and Jeong 2010, 29). They argue that there is a correlation between this positive portrayal on television and the perceived prevalence of having fewer children. Their study was developed amid a growing concern that soaps and dramas 'contributed to an antibaby mood depicting single-life as "cool" and raising children as a "burden"' (Jin and Jeong 2010, 17). As a result, the authors conclude by recommending that 'health-policy makers need to encourage television drama writers to be more considerate in producing television soap contents, and strive to highlight the preciousness of married life, family, and raising children via television' (Jin and Jeong 2010, 30). Irrespective of whether or not one would support Jin and Jeong's recommendations, their very concern underscores the fact that secondwave dramas run counter to hegemonic cultural narratives of the 'traditional' productive family, highlighting the critical role that these dramas play in contemporary Korean society. Certainly for second-wave Korean dramas we need to move beyond the simplistic notion that 'ideological messages constitute a key component of Hallyu' (Tran 2015, 58). 
When the first author originally started working on this project as a visiting professor in a Korean university, he had the opportunity to discuss the project with senior male Korean colleagues. His colleagues were somewhat bemused and they were clearly not convinced by the validity of the project. One of the professors actually felt comfortable enough to offer some heartfelt advice: 'If you want to know what Korean people think then use literature, not TV dramas.' Needless to say, he personally did not watch any dramas. Popular culture and melodrama have a long history of being considered either as an inferior form of culture or as a form of dangerous alienation. This critique has also been extended to Korean dramas. From our experience, audiences of Korean dramas are far too often dismissed through (misogynistic?) clichés. In our paper we have sought to show that there has been a quiet revolution in the domain of Korean drama which shows a far more complex reality than has been generally assumed. As such, we cannot support the conclusion that we are facing 'weak-minded audiences' brainwashed by fantastical situations (Tran 2015, 59). As we have shown in our study, Korean dramas are used to critically reflect, or indeed to communicate, the social problems facing their audiences rather than reproducing hegemonic ideals. ${ }^{5}$ Our informants did not seek to escape reality through dramas but paradoxically turned to dramas in order to expose the inconvenient realities of Korean society, which included themes such as corruption, societal pressures in education and problems facing women and young people. Indeed, all of our informants were critical of dramas which were considered too mello (melodramatic) and such dramas were often derided as being makjang (unrealistic).

While the Korean government has been keen to highlight the international success of Korean dramas, it is important to remember that such dramas are produced first for a domestic audience. We would argue that Korean dramas are primarily domestic texts produced by and for a Korean society. Focusing on the meanings and role of Korean dramas for an international audience might occlude the meanings of a cultural text. Korean dramas cannot be reduced to their 'Hallyuisation'. How a drama is viewed and what it means can change dra-

5 That being said, certain more critical or complex dramas such as Weightlifting Fairy Kim BokJoo (2016) or Because This is My First Life (2017) do not attain the popularity of the dramas discussed throughout this text. The latter in particular was virtually unknown among our informants. It features a complex narrative acting as a metatextual commentary on the Korean drama industry itself. The main plot features a Korean drama writer who loses her job after she rejects the sexual advances of a male co-writer and, in order to get a cheaper rent and satisfy parental pressures, agrees to get married to a male roommate who, for equally pragmatic reasons, proposes to her. They therefore draw up a contract outlining mutual obligations in an asexual marriage. (See Park and Baldacchino, forthcoming.) 
matically when comparing the international audience with the domestic one. The meanings of the text cannot be understood outside the cultural context of its production and consumption. In turn, the reasons for their popularity overseas and their domestic appeal may very well be markedly different. While focusing on the international success of Korean drama might serve a broader geo-political or economic purpose at underscoring the global success of the Korean cultural industries, the way that we have encountered these texts arose from the lives of our Korean informants embedded in Korean social realities. We would even go a step further: as shown in our discussion, these dramas are texts which are ultimately embedded in highly localised referents $(M y I D$ is Gangnam Beauty, SKY Castle), highly localised contexts of class and gender which attest to the fact that these are texts produced primarily for a domestic audience. It is only in a moment of secondary elaboration that these texts become signifiers of an imagined Korea consumed by international audiences. Existing studies of Hallyu have already shown us how Korean drama can speak to very specific cultural contexts of modernity where race and class are implicated in complex ways (B.M. Han 2019; Hong 2013; Hu 2010). Future studies might seek to create a more focused comparison between the domestic interpretation of a text and its international audience. It is time to turn the tide of Hallyu studies back to its local context. It is only then that we can truly appreciate the impact and reach of the globalisation of Korean drama. At the very least we can then begin to appreciate the agency of these Korean young women and recover their voice in a way that challenges the often misogynistic understanding of their viewership.

\section{Acknowledgments}

This research was supported by the Academy of Korean Studies Grant (AKs2018-Ro6).

\section{References}

Abelmann, N. 2003. The Melodrama of Mobility. Honolulu: University of Hawaiii Press.

Baldacchino, J. 2008. 'Eros and Modernity: Convulsions of the Heart in Modern Korea'. Asian Studies Review, 32(1): 99-122.

Baldacchino, J. 2014. 'In Sickness and in Love? Autumn in My Heart and the Embodiment of Morality in Korean Television Drama'. Korea Journal 54(4): $5^{-28}$.

Cheon, J.H. 2019. ‘드라마 〈스카이 캐슬〉과 신재민 사건에 나타난 학벌.계급.가족' [Education, 
Class and Family in Sky Castle and Sin Jae-Min Incident]. Critical Review of History 126: $423-45$ o.

Chiesa, L. 2007. Subjectivity and Otherness. Cambridge, MA: MIT Press.

Cho, M. 2014. 'Face Value: The Star as Genre in Bong Joon-Ho's Mother'. In The Korean Popular Culture Reader, edited by K.H. Kim and Y. Choe, 168-195. Durham, NC: Duke University Press.

Elfving-Hwang, J. 2017. 'Aestheticizing Authenticity: Corporate Masculinities in Contemporary South Korean Television Dramas'. Asia Pacific Perspectives 15(1): 55-72.

Eun, S. 2013. 'Brilliant Hallyu and Plastic Surgery'. Journal of Korean Medical Science 28(11): 1561-1562.

Fink, B. 2016. Lacan on Love. Cambridge: Polity Press.

Flamm, P. 2018. 'No Country for Blue Helmets: South Korean National Identity on the Screen in "Descendants of the Sun"'. The Asia-Pacific Journal 11(3):1-14.

Frater, P. 2019 (13 June). 'Netflix Expands Korean Content Commitment as Industry Deepens'. Variety Online, https://variety.com/2019/digital/asia/netflix-expandskorea-content-commitment-1203243097/.

Han, B.M. 2019. 'Fantasies of Modernity: Korean Tv Dramas in Latin America'. Journal of Popular Film and Television 47(1): 39-47.

Han, G. 2019. 'TV 드라마 〈sKY 캐슬〉에 나타난 욕망.응시.주체화' [Desire, Gaze and Subjectification in the TV Drama Sky Castle]. Korean Language Education 165: 299-329.

Hong, S.K. 2013. 세계화와 디지털 문화 시대의 한류 [Hallyu in Globalization and Digital Culture Era]. Paju: Hanulbooks.

Hong, S.K. 2014 (October). '프랑스의 한국 드라마 수용' [The Reception of Hallyu in France]. Proceedings of Korean Association of Studies in French Annual Conference $7: 23-44$.

Hong-Mercier, S.K. 2013. '세계화 과정 속 디지털 문화 현상으로서의 한류: 프랑스에서 바라본 한류의 세계적 소비에 대한 이론적 고찰' [Hallyu as a Digital Culture Phenomenon in the Process of Globalization: A Theoretical Investigation on the Global Consumption of Hallyu seen in France]. Journal of Communication Research 5O(1): 157-192.

Hu, B. 2010. 'Korean Tv Serials in the English-Language Diaspora: Translating Difference Online and Making it Racial'. The Velvet Light Trap 66: $36-49$.

Hwang, Y.M. 2011. South Korean Historical Drama: Gender, Nation and the Heritage Industry. Unpublished $\mathrm{PhD}$ thesis submitted to the University of St Andrews.

Jin, B., and S. Jeong. 2010. 'The Impact of Korean Television Drama Viewership on the Social Perceptions of Single Life and Having Fewer Children in Married Life'. Asian Journal of Communication 20(1): 17-32.

Jin, D.Y. 2016. New Korean Wave: Transnational Cultural Power in the Age of Social Media. Urbana: University of Illinois Press.

Kang, S.H., Y.H. Im and T.M. Noh. 2012. '멜로드라마 보는 남자들: 중년 남성의 여성 장르 시청 경험에 관한 연구’ [Men Watching Melodrama:The Middle-Aged Male's Viewing 
Experience of Women's Genre]. Korean Journal of Communication and Information 58: 201-221.

Kim, H.K. 2018. '막장 코드 벗은 드라마: 세계는 지금 “한드” 시대' [Dramas Stripped of 'makjang' Code: The World is Now Facing Hallyu Times]. n·content 6(5-6): 22-25.

Kim, H.M. 2005. 'Korean TV Dramas in Taiwan: With an Emphasis on the Localization Process'. Korea Journal 45(4): 183-205.

Kim, J. 2019. 'Korean Popular Cinema and Television in the Twenty-First Century: Parallax Views on National/Transnational Disjunctures'. Journal of Popular Film and Television 47(1): 2-8.

Kim, T. 2003. 'Neo-Confucian Body Techniques: Women's Bodies in Korea's Consumer Society'. Body and Society 9(2): 97-113.

Korea Creative Content Agency (KOCCA). 2014. '드라마 편성, 제작 그리고 내용 분석' [Drama Programming, Production and Contents Analysis] (Research Report No. 1439), http://www.kocca.kr (accessed 1 November 2019).

Korean Foundation for International Cultural Exchange (KOFICE). 2017. 한류백서 2017 [Hallyu White Paper 2017], http://kofice.or.kr (accessed 29 October 2019).

Korean Foundation for International Cultural Exchange (KOFICE). 2018. 한류 백서 2018 [Hallyu White Paper 2018], http://portal.kocca.kr/ (accessed 29 October 2019).

Kuwahara, Y. 2014. 'Hanryu: Korean Popular Culture in Japan'. In The Korean Wave: Korean Popular Culture in Global Context, edited by Y. Kuwahara, 213-221. New York: Palgrave Macmillan.

Lacan, J. 2008. My Teaching. London: Verso.

Lee, H. 2010. 'Buying Youth: Japanese Fandom of the Korean Wave'. In Complicated Currents: Media Flows, Soft Power and East Asia, edited by D. Black, S. Epstein and A. Tokita, 7.1-7.16. Clayton, VA, Australia: Monash University Publishing.

Lee, S. 2012. 'The Structure and Appeal of Korean Wave Texts'. Korea Observer 43(3): 447-469.

Lee, S.Y. 2008. 한류 드라마와 아시아 여성의 욕망 [Hallyu Dramas and the Desire of Asian Women]. Seoul: Communication Books.

Lett, D.P. 1998. In Pursuit of Status: The Making of South Korea's 'New' Urban Middle Class. Cambridge, MA: Harvard University Asia Center.

Lin, X., and R. Rudolf. 2017. 'Does K-Pop Reinforce Gender Inequalities? Empirical Evidence from a New Data Set'. Asian Women 33(4): 27-54.

Mōri, Y. 2008. 'Winter Sonata and Cultural Practices of Active Fans in Japan'. In East Asian Pop Culture, edited by B.H. Chua and K. Iwabuchi, 127-143. Hong Kong: Hong Kong University Press.

Park, E., and J. Baldacchino. Forthcoming. '연애의 변화와 공동체적 연대: 드라마 < 이번생은 처음이라〉와 〈멜로가 체질〉을 중심으로' (From romantic love to communal solidarity: Because this is my First Life and Melo is my Nature).

Park, J.H., Y.S. Lee and H. Seo. 2019. 'The Rise and Fall of Korean Drama Export to China: 
The History of State Regulation of Korean Dramas in China'. International Communication Gazette 81(2): 139-157.

Park, J.S. 2014. 한류학 개론 [Introduction to Hallyuology]. Seoul: Seon Publishing.

Park, N.H. 2013. '텔레비전 드라마와 한류 담론: 한류 진화론과 위기론에 대한 비판적 고찰을 중 심으로' [Television Drama and Discourse of Korean Wave: A Critical Study Focused on the Korean Wave Evolution Theory and Crisis Theory]. Studies in Korean Literature 45: 337-368.

Prado, K.M.N. 2017. 'Hallyu:Through the Looking Glass'. AIKs Korean Studies Conference Proceedings 4:142-158.

Seth, M.J. 2002. Education Fever: Society, Politics, and the Pursuit of Schooling in South Korea. Honolulu: University of Hawai'i Press.

Shim, D.B. 2003. '한류와 한국 드라마, 그리고 여성의 팬덤' [Korean Wave, Korean Drama and Women's Fandom]. Journal of Broadcast Engineering 12(5): 414-422.

Storey, J. 2015. Cultural Theory and Popular Culture: An Introduction. Abingdon and New York: Routledge.

Tran, D.T. 2015. The Obsession of Aesthetics Plastic Surgery: The Deconstruction of an Artificially Obsessed South Korean Society. New York: Atropos Press.

Walsh, J. 2014. 'Hallyu as a Korean Government Construct: The Korean Wave in the Context of Economic Social Development'. In The Korean Wave: Korean Popular Culture in Global Context, edited by Y. Kuwahara, 13-33. Hong Kong: Hong Kong University Press.

Yang, F.I. 2008a. 'Engaging with Korean Dramas: Discourses of Gender, Media, and Class Formation in Taiwan'. Asian Journal of Communication 18(1): 64-79.

Yang, F.I. 20o8b. 'The Gentrification of "Korean Drama” in Taiwan'. China Information 22(2): 277-304.

Yun, H.J., and H.M. Kang. 2014. '드라마 〈응답하라 1994〉의 문화 코드 연구' [What Does the TV Drama Say? An Analysis on the Culture Code of Soap Opera Respond 1994]. Journal of Cultural Exchange 3(1): 49-65. 